\title{
THE SOVIET MEMORANDUM ON THE ANTARCTIC, 1950
}

[The following Memorandum was sent by the Soviet Government on 7 June 1950 to the Governments of the United States, the United Kingdom, France, Norway, Australia, Argentina and New Zealand, and is translated from the text published by Tass in Pravda on 10 June 1950. The Soviet claim to participate in the settlement of Antarctic questions is based partly on "historical rights"; this aspect has been examined in the Polar Record, Vol. 5, No. 39,1950 , p. $475-78$, and in this issue on p. 85-87.]

\section{Translation:}

"Since the autumn of 1948 a number of statements of the Ministries of Foreign Affairs of the U.S.A., Great Britain and some other countries, and reports in the world press, have referred to the negotiations on the Antarctic which were begun on the initiative of the U.S. State Department between the United States of America, Great Britain, France, Norway, Australia, New Zealand, Argentina and Chile. From these same statements of the representatives of the Ministries of Foreign Affairs of some states and from press reports it follows that the aim of the negotiations is a decision of the question of the régime for the Antarctic.

"The Government of the U.S.S.R. cannot agree that such a question as the question of the régime for the Antarctic should be decided without their participation. In this connection the Soviet Government consider it necessary to recall the outstanding services of Russian navigators in the discovery of the Antarctic. The fact is generally recognized that the Russian navigators Bellingshausen and Lazarev, at the beginning of the nineteenth century, were the first to reach the shores of the Antarctic, that they circumnavigated the continent and proved thereby the erroneousness of the view which was widely held at the time that there was no land beyond the antarctic circle. This service of the Russian navigators is no less important than the later explorations on the continent itself and on its shores, carried out by the expeditions of some countries whose representatives are now declaring their interest in the determination of the regime for the Antarctic.

"It is common knowledge that the territory of the Antarctic and the waters adjacent to it are of great value economically, and from this aspect the Antarctic continent is of significance not only to the states enumerated above which are taking part in the negotiations on the régime for the Antarctic, but also to many other states, including the Soviet Union. It is sufficient to say that nine-tenths of the world catch of whales comes specifically from antarctic waters. The U.S.S.R. is a participant in the whaling industry and in the International Whaling Convention of 1946. Its whaling flotillas regularly participate in the whaling trade in antarctic waters.

"The same state of affairs may be observed as regards the scientific significance of the Antarctic; since this continent and the adjacent islands are a convenient base for most important meteorological observations which are also of significance to the northern hemisphere.

"The attention of the Soviet public has already been drawn to these facts. In particular they were commented upon in the resolution of a general meeting of the Geographical Society of the U.S.S.R. [Vsesoyuznoye Geograficheskoye 
Obshchestvo] of 10 February 1949 , in which the Society stressed the very great importance of the discoveries of Russian navigators in the Antarctic.

"The Soviet Government consider it necessary to state that in accordance with international practice all interested countries should be enlisted for the discussion of the régime for any area of international significance. The Soviet Government consider that this international practice should also be observed in deciding the question of the Antarctic. It has already had occasion to point to the illegality of a separate solution of the question of the state affiliation of the Antarctic in an official note to the Norwegian Government dated 27 January 1939.1

"Because of the above, the Soviet Government cannot recognize as legal any decision on the régime for the Antarctic taken without their participation. They consider that because the fate of the Antarctic is of interest to many countries it would be expedient at the present time to discuss internationally the question of the régime for the Antarctic, having in view the achievement of an agreement such as would accord with the legitimate interests of all interested states.

"The Soviet Government for their part are prepared to examine any proposals of the interested governments both regarding the procedure for the discussion of this question and the nature of the régime for the Antarctic."

1 This Soviet note contested the right of the Norwegian Government to annex Peter I $\emptyset_{y}$. -Eds. 